\title{
Ambient aromatic hydrocarbon measurements at Welgegund, South Africa
}

\author{
K. Jaars ${ }^{1}$, J. P. Beukes ${ }^{1}$, P. G. van Zyl ${ }^{1}$, A. D. Venter ${ }^{1}$, M. Josipovic ${ }^{1}$, J. J. Pienaar ${ }^{1}$, V. Vakkari ${ }^{2,3}$, H. Aaltonen ${ }^{2}$, \\ H. Laakso ${ }^{3}$, M. Kulmala ${ }^{3}$, P. Tiitta ${ }^{1,4}$, A. Guenther ${ }^{5}$, H. Hellén ${ }^{2}$, L. Laakso ${ }^{1,2}$, and H. Hakola ${ }^{2}$ \\ ${ }^{1}$ Unit for Environmental Sciences and Management, North-West University, Potchefstroom, South Africa \\ ${ }^{2}$ Finnish Meteorological Institute, PL 503, 00101 Helsinki, Finland \\ ${ }^{3}$ Department of Physics, University of Helsinki, Helsinki, Finland \\ ${ }^{4}$ Fine Particle and Aerosol Technology Laboratory Department of Environmental Science, University of Eastern Finland \\ ${ }^{5}$ Pacific Northwest National Laboratory, Richland, WA, USA
}

Correspondence to: P. G. van Zyl (pieter.vanzyl@nwu.ac.za)

Received: 25 October 2013 - Published in Atmos. Chem. Phys. Discuss.: 17 February 2014

Revised: 16 May 2014 - Accepted: 5 June 2014 - Published: 11 July 2014

\begin{abstract}
Aromatic hydrocarbons are associated with direct adverse human health effects and can have negative impacts on ecosystems due to their toxicity, as well as indirect negative effects through the formation of tropospheric ozone and secondary organic aerosol, which affect human health, crop production and regional climate. Measurements of aromatic hydrocarbons were conducted at the Welgegund measurement station (South Africa), which is considered to be a regionally representative background site. However, the site is occasionally impacted by plumes from major anthropogenic source regions in the interior of South Africa, which include the western Bushveld Igneous Complex (e.g. platinum, base metal and ferrochrome smelters), the eastern Bushveld Igneous Complex (platinum and ferrochrome smelters), the Johannesburg-Pretoria metropolitan conurbation ( $>10$ million people), the Vaal Triangle (e.g. petrochemical and pyrometallurgical industries), the Mpumalanga Highveld (e.g. coal-fired power plants and petrochemical industry) and also a region of anticyclonic recirculation of air mass over the interior of South Africa. The aromatic hydrocarbon measurements were conducted with an automated sampler on TenaxTA and Carbopack-B adsorbent tubes with heated inlet for 1 year. Samples were collected twice a week for $2 \mathrm{~h}$ during daytime and $2 \mathrm{~h}$ during night-time. A thermal desorption unit, connected to a gas chromatograph and a mass selective detector was used for sample preparation and analysis. Results indicated that the monthly median (mean) total aromatic hydrocarbon concentrations ranged between 0.01
\end{abstract}

(0.011) and 3.1 (3.2) ppb. Benzene levels did not exceed the local air quality standard limit, i.e. annual mean of $1.6 \mathrm{ppb}$. Toluene was the most abundant compound, with an annual median (mean) concentration of $0.63(0.89) \mathrm{ppb}$. No statistically significant differences in the concentrations measured during daytime and night-time were found, and no distinct seasonal patterns were observed. Air mass back trajectory analysis indicated that the lack of seasonal cycles could be attributed to patterns determining the origin of the air masses sampled. Aromatic hydrocarbon concentrations were in general significantly higher in air masses that passed over anthropogenically impacted regions. Inter-compound correlations and ratios gave some indications of the possible sources of the different aromatic hydrocarbons in the source regions defined in the paper. The highest contribution of aromatic hydrocarbon concentrations to ozone formation potential was also observed in plumes passing over anthropogenically impacted regions.

\section{Introduction}

Atmospheric measurements - which include, but are not limited to, speciated volatile organic compounds and other trace gasses, as well as size-resolved aerosols - are well established in developed countries. However, less emphasis is placed on such environmental issues in developing countries, since resources are mostly utilised for economic growth. For 
this reason, Africa is one of the least studied regions with respect to air quality (Laakso et al., 2006). South Africa has the largest industrialised economy in Africa and is known for its diverse anthropogenic pollutant sources, which include agriculture, metallurgical and mining operations, coal-fired power generation, petrochemical operations, coal dumps and transportation (Lourens et al., 2011). Unique meteorological conditions are prevalent in South Africa, which include relatively high atmospheric temperatures and solar radiation, which increases photochemical activity in the atmosphere, and dominant anticyclonic climatology and the presence of low-level inversion layers in winter cause trapping of pollutants (Tyson et al., 1996).

Atmospheric volatile organic compounds (VOCs) are emitted from both natural and anthropogenic sources (Bates et al., 2000; Brasseur et al., 1999; Hewitt, 1999). Anthropogenic VOC emissions result from petrochemical industries, combustion processes (e.g. fossil fuel, power plants), vehicular emissions, storage and transport of fuel, usage and production of solvents, hazardous waste facilities and landfills (Srivastava et al., 2005; Derwent et al., 2000; Kourtidis et al., 1999; Jose et al., 1998). Biomass burning (veld fires) can also be an important source of VOCs, especially in southern Africa, where large-scale biomass combustion occurs every year in the dry season (e.g. Crutzen and Andreae, 1990; Crutzen et al, 1979). However, these emissions are difficult to evaluate, as they are highly dependent on fuel type, humidity and burn rate (Lobert et al., 1990).

A large fraction of anthropogenic VOCs consists of aromatic hydrocarbons, of which benzene; toluene; ethylbenzene; and $o-, m$ - and $p$-xylene (BTEX) are the most commonly measured compounds. Aromatic hydrocarbons participate in complex chemical reactions in the atmosphere to form secondary pollutants. Although reactions of aromatic hydrocarbons do not directly produce ozone $\left(\mathrm{O}_{3}\right)$, they play a role in $\mathrm{O}_{3}$ formation when they are oxidised by the hydroxyl radical $\left({ }^{\circ} \mathrm{OH}\right)$ in the troposphere, producing peroxy radicals $\left(\mathrm{RO}_{2}^{*}\right)$ and hydroperoxy radicals $\left(\mathrm{HO}_{2}^{*}\right)$, which then oxidise nitric oxide (NO), which removes a sink for $\mathrm{O}_{3}$ (Atkinson, 2000). Aromatic hydrocarbons can also react with nitrate radicals $\left(\mathrm{NO}_{3}^{*}\right)$ (Atkinson, 1994; Penkett et al., 1993) and halogen radicals (Finnlayson-Pitts et al., 1986). Various researchers have investigated gas-phase photooxidation of aromatic hydrocarbons (e.g. Birdsall et al., 2010; Arey et al., 2009; Coeur-Tourneur et al., 2006; Johnson et al., 2004, 2005; Takekawa et al., 2003; Calvert et al., 2002, and references therein; Olariu et al., 2002; Volkamer et al., 2002).

VOCs are also associated with adverse human health effects (Mukund et al., 1996; Kostiainen, 1995; Sweet and Vermette, 1992; Edgerton et al., 1989; Duce et al., 1983) and can also be harmful to ecosystems (Atkinson, 2000; Dewulf and Van Langenhove, 1997; Kuran and Sojak, 1996; Derwent, 1995). Benzene, for instance, is known as a genotoxic carcinogen (Hellén et al., 2002; WHO, 2000) and is closely linked to the induction of leukaemia. Studies have also indi- cated that VOCs can have detrimental impacts on crop production, which is important for global food security (Zunckel et al., 2006).

Limited research has been conducted to determine the emission rates of biogenic VOCs in southern Africa (Harley et al., 2003; Otter et al., 2002a, 2002b; Swap et al., 2002a, 2002b; Greenberg et al., 2002; Greenberg et al., 1999; Guenther et al., 1996). Even fewer data are available to characterise aromatic VOC levels in South Africa. Benzene is the only aromatic hydrocarbon that has a standard included in the National Ambient Air Quality Standards (NAAQS) (Government Gazette, 2009). According to the knowledge of the authors, only Lourens et al. (2011) has conducted a study in this region on BTEX concentrations that was published in the peer-reviewed public domain. This study was limited to measurements in the industrialised Mpumalanga Highveld and Vaal Triangle for 1 year. Additionally, some postgraduate studies focusing on BTEX have been conducted (van der Walt, 2008; Burger, 2006; Chiloane, 2005), but these were not published in the peer-reviewed public domain. Various industries also perform VOC measurements in South Africa to comply with legislation, but these results are in most instances not peer-reviewed and not available in the public domain.

To at least partially address the above-mentioned knowledge gap, i.e. very limited data on atmospheric aromatic hydrocarbons in South Africa, measurements were conducted for 1 year at the Welgegund measurement station. This station was strategically positioned to enable measurements of air masses that have passed over the regional background, as well as all the major anthropogenic source regions in South Africa (Beukes et al., 2014).

\section{Measurement location and methods}

\subsection{Site description}

The Welgegund measurement station (www.welgegund.org) is situated approximately $100 \mathrm{~km}$ west of Johannesburg (Fig. 1) on the property of a commercial farmer. The station is considered to be a regionally representative background site with no direct impacts from pollution sources in close proximity. The entire western sector (from north to south-east) contains no major point sources and can therefore be considered as representative of a relatively clean regional background. The site is, however, impacted by plumes from major anthropogenic source regions in the interior of South Africa, which include the western Bushveld Igneous Complex (WBIC), the eastern Bushveld Igneous Complex (EBIC), the Johannesburg-Pretoria metropolitan conurbation ( $>10$ million people), the Vaal Triangle, the Mpumalanga Highveld and also a region of anticyclonic recirculation of air mass over the interior of South Africa. The impacts of regional biomass combustion occurring mainly in 


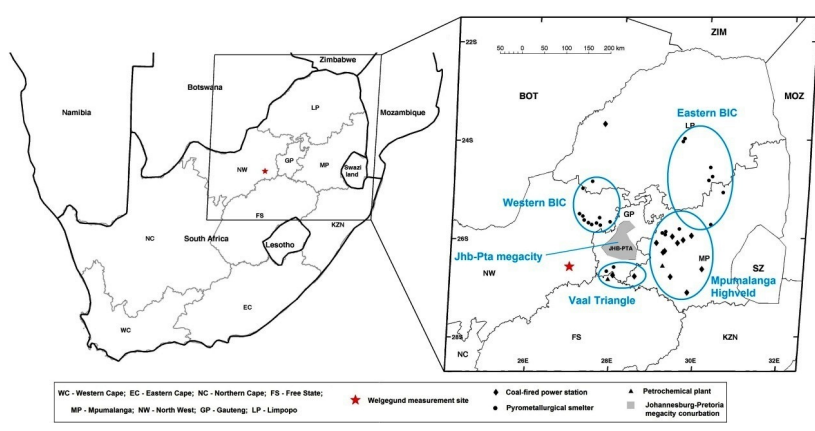

Figure 1. Map of southern Africa indicating the location of the Welgegund measurement station, large point sources in the industrial hub of South Africa and anthropogenic source regions impacting Welgegund.

the dry winter and spring are also observed at Welgegund. A detailed description of the Welgegund measurement station and related source regions was recently presented by Beukes et al. (2014). In Fig. 1, the location of Welgegund is indicated (latitude $26^{\circ} 34^{\prime} 10^{\prime \prime} \mathrm{S}$, longitude $26^{\circ} 56^{\prime} 21^{\prime \prime} \mathrm{E} ; 1480 \mathrm{~m}$ a.s.1.) within a regional perspective, which also indicates the large point sources and source regions.

\subsection{Measurement methods}

The measurement instruments were placed inside a Eurowagon $4500 \mathrm{u}$ (length $4.5 \mathrm{~m}$, width $2.1 \mathrm{~m}$, height $2.3 \mathrm{~m}$ ) measurement container. A detailed description of the measurement instruments, operation procedures and data analysis, as well as calibration and maintenance procedures has been presented by Beukes et al. (2014), Tiitta et al., 2014, Petäjä et al. (2013), Hirsikko et al. (2012), Venter et al. (2012), Vakkari et al. (2011) and Laakso et al. (2008).

\subsubsection{Aromatic hydrocarbon measurements}

The VOC measurement campaign was conducted for 1 year (9 February 2011 to 4 February 2012) to observe seasonal variability. Samples were collected twice a week for $2 \mathrm{~h}$ during daytime (11:00 to 13:00 local time, LT) and $2 \mathrm{~h}$ during night-time (23:00 to 1:00 LT) on Tuesdays and Saturdays. Obviously this repetitive sampling schedule, i.e. same days each week and same hours of the day, was prone to some bias. Large point sources, i.e. industrial stack emissions, in South Africa are regulated on an availability basis. This implies that off-gas cleaning equipment must be operational for a certain percentage of the overall operating time (typically 97-99\%) and not on a time basis, e.g. specific days or hours when emissions are allowed. It was therefore impossible to set a sampling schedule to capture possible large releases of VOCs by such point sources. Traffic emissions, which can be considered as a point or area source, depending on how far the emissions are from the measurement site, are another example of a potential time-bound VOC source that had to be considered. At the Welgegund site only a small gravel road, used by a few farmers, is nearby. Local traffic emissions are therefore almost negligible. Large traffic volumes in especially the Johannesburg-Pretoria megacity could be a significant area source of VOCs for Welgegund. However, since Welgegund is $\sim 100 \mathrm{~km}$ west of Johannesburg, it was difficult to set a sampling schedule to capture such time-bound emissions that are transported at different rates on different days with different meteorological conditions. Considering the remote nature of the sampling site and logistical limitations during the sampling campaign, the sampling schedule applied was the most feasible option that enabled the collection of a full year of data. VOCs were sampled at a height of $2 \mathrm{~m}$ above ground level, with a $1.75 \mathrm{~m}$ long inlet. The first $1.25 \mathrm{~m}$ of the inlet was made of stainless steel and the second $0.5 \mathrm{~m}$ of Teflon. The first $1.2 \mathrm{~m}$ of the stainless steel section of the inlet was heated to $120^{\circ} \mathrm{C}$ using heating cables and thermostats (Thermionic) to remove $\mathrm{O}_{3}$, which could possibly lead to sample degradation (Hellén et al., 2012). The last $0.05 \mathrm{~m}$ of the stainless steel section and the entire Teflon section was housed within the measurement container, wherein the temperature was regulated at $24{ }^{\circ} \mathrm{C}$. The $\mathrm{O}_{3}$ removal efficiency was checked with an $\mathrm{O}_{3}$ monitor at regular intervals, which revealed that $\mathrm{O}_{3}$ concentrations decreased from median values $\geq 30 \mathrm{ppb}$ (Beukes et al., 2014) to $<2 \mathrm{ppb}$.

Prior to sampling, all adsorbent tubes were tested for leaks and preconditioned with helium for $30 \mathrm{~min}$ at $350{ }^{\circ} \mathrm{C}$ at a flow of $40 \mathrm{~mL} \mathrm{~min}^{-1}$. After treatment, the tubes were sealed with Swagelok® brass 0.25 in. caps and stored in a fridge at temperatures below $18^{\circ} \mathrm{C}$ before they were transported to the field for sampling. VOC samples were collected on TenaxTA and Carbopack-B adsorbent tubes $(6.3 \mathrm{~mm} \mathrm{ED} \times 90 \mathrm{~mm}$, $5.5 \mathrm{~mm}$ ID) by using a constant-flow-type automated programmable sampler. A needle valve attached to the pump was used to keep the flow constant, while magnetic valves were used to direct flow to a specific sample tube. After a specific tube was sampled, the tube was automatically sealed off and the next tube selected for sampling. The flow of the pump was calibrated each week. A sampling flow between 100 and $110 \mathrm{~mL} \mathrm{~min}^{-1}$ was used throughout the study. Hellén et al. (2002) reported no breakthrough for Tenax-TA and Carbopack-B tubes when sampling for $4 \mathrm{~h}$ at a flow rate of $100 \mathrm{~mL} \mathrm{~min}^{-1}$. Once a week, the tubes were removed from the automated sampler and closed with Swagelok ${ }^{\circledR}$ caps. Each tube was separately wrapped in aluminium foil and stored in a container for transport to the laboratory. Tubes were stored in the laboratory in a freezer within a clean environment to minimise pre-analysis elution and breakdown of the sampled compounds. For each month, a field blank was analysed to compensate for the possibility of contamination from sample handling and storage. The total concentration of aromatic hydrocarbons in all field blanks was found to be $<0.076 \mathrm{ppb}$. Actual concentrations of all compounds reported in this paper were significantly higher than blank 
values and also well above the detection limits. Blank values were subtracted from exposed samples.

The analyses and preparation of the adsorbent tubes were done by the Finnish Meteorological Institute. The instrumental setup was a thermal desorption instrument (Perkin-Elmer TurboMatrix $^{\mathrm{TM}} 650$, Waltham, USA) connected to a gas chromatograph (Perkin-Elmer ${ }^{\circledR}$ Clarus ${ }^{\circledR}$ 600, Waltham, USA) with a DB-5MS $(60 \mathrm{~m}, 0.25 \mathrm{~mm}, 1 \mu \mathrm{m})$ column and a mass selective detector (Perkin-Elmer ${ }^{\circledR}$ Clarus $^{\text {o }}$ 600T, Waltham, USA). The sample tubes were desorbed at $300^{\circ} \mathrm{C}$ for $5 \mathrm{~min}$ and cryofocused in a Tenax cold trap $\left(-30^{\circ} \mathrm{C}\right)$ prior to injection of the sample into the column by rapidly heating the cold trap $\left(40^{\circ} \mathrm{C} \mathrm{min}^{-1}\right)$ to $300^{\circ} \mathrm{C}$. A three-point calibration curve was obtained by using liquid standards dissolved in methanol. Standard solutions were injected into adsorbent tubes and were flushed with nitrogen $\left(100 \mathrm{~mL} \mathrm{~min}^{-1}\right)$ for $10 \mathrm{~min}$ in order to evaporate the methanol. The tubes containing the standards were desorbed and analysed with the same method used for the sampled tubes. Thirteen aromatic hydrocarbons were detected and quantified during this study.

\subsubsection{Ancillary measurements}

Trace gas measurements continuously conducted at Welgegund were used to assist in the interpretation of aromatic hydrocarbon results obtained. These were measured by utilising a Thermo-Electron $43 \mathrm{~S}$ sulfur dioxide $\left(\mathrm{SO}_{2}\right)$ analyser (Thermo Fisher Scientific Inc., Yokohama-shi, Japan), a Teledyne 200AU $\mathrm{NO}_{\mathrm{x}}$ analyser (Advanced Pollution Instrumentation Inc., San Diego, CA, USA), an Environment $\mathrm{SA} 41 \mathrm{M} \mathrm{O}_{3}$ analyser (Environment SA, Poissy, France) and a Horiba APMA-360 CO analyser (Horiba, Kyoto, Japan). A more detailed description of additional parameters monitored at Welgegund is given by Beukes et al. (2014) and Petäjä et al. (2013).

\subsubsection{Air mass back trajectory analysis}

Individual hourly back trajectories were calculated with the Hybrid Single-Particle Lagrangian Intergrated Trajectory (HYSPLIT) model version 4.8, developed by the National Oceanic and Atmospheric Administration (NOAA) Air Resources Laboratory (ARL) (Draxler and Hess, 2004). This model was run with meteorological data of the GDAS archive of the US National Weather Service's National Center for Environmental Prediction (NCEP) and archived by the ARL (Air Resources Laboratory, 2012). Each hourly arriving back trajectory was calculated for $96 \mathrm{~h}$ (4 days) backwards. An arrival height of $100 \mathrm{~m}$ was chosen, since aromatic hydrocarbons are mainly emitted within the lowermost layer of the troposphere. Furthermore, the orography in HYSPLIT is not very well defined, and therefore lower arrival heights could result in larger error margins on individual trajectory calculations. Back trajectories were calculated for the start, middle and end of each measurement period, i.e. 3-hourly arriving back trajectories calculated for each $2 \mathrm{~h}$ sample.

\section{Results and discussion}

\subsection{Contextualising aromatic hydrocarbon concentrations measured at Welgegund}

The monthly mean (median) aromatic hydrocarbon concentrations determined in this study ranged between $0.011(0.01)$ and $3.2(3.1) \mathrm{ppb}$ ). As previously mentioned, benzene is currently the only VOC listed as a criteria pollutant in the NAAQS (Lourens et al., 2011; Government Gazette, 2009), with an annual average limit of $1.6 \mathrm{ppb}$ (2015 standard). The Welgegund annual mean (median) benzene concentration was $0.29(0.13) \mathrm{ppb}$, which is well below the South African standard. The highest benzene concentration measured was $8.7 \mathrm{ppb}$, which indicates that the site is occasionally significantly impacted by pollution sources. Liu et al. (2000), who conducted a study in a relatively non-polluted area in the northeast of China, reported an average benzene concentration of $9.4 \mu \mathrm{g} \mathrm{m}^{-3}$ (2.94 ppb). Lourens et al. (2011) reported an annual median of $0.91 \mathrm{ppb}$ in the Mpumalanga Highveld and the Vaal Triangle, which is higher than the annual median value measured at Welgegund. This can be attributed to the measurement sites in the Mpumalanga Highveld and the Vaal Triangle being closer to the large point sources than Welgegund. In another investigation, van der Walt (2008) measured benzene levels in a South African metropolitan area and reported an annual mean of $1.8 \mathrm{ppb}$. A comparison of the benzene concentrations measured at Welgegund with these studies indicates that Welgegund can be considered as a regional background site that is on occasion impacted by major plumes from different sources.

Toluene was the most abundant aromatic hydrocarbon, with an annual mean (median) concentration of 0.89 $(0.63) \mathrm{ppb}$ - nearly 5 times higher than the benzene annual median concentration. Lourens et al. (2011) also reported ambient toluene concentrations to be substantially higher than that of benzene over the interior of South Africa. Considering that toluene also has negative effects on human health, as well as that it is a precursor for $\mathrm{O}_{3}$ and secondary organic aerosol formation, it should be considered to be included in future South African air quality legislation.

The second and third most abundant aromatic hydrocarbons measured were styrene and $(m, p)$-xylene with annual mean (median) concentrations of $0.83(0.66)$ and 0.77 $(0.50) \mathrm{ppb}$, respectively. $o$-Xylene and ethyl benzene had annual mean (median) concentrations of $0.30(0.20)$ and 0.34 $(0.25) \mathrm{ppb}$, respectively. The other aromatic hydrocarbons measured had annual median concentrations that were significantly lower. This does not necessarily mean that their emission sources were lower, since the ambient concentrations are 

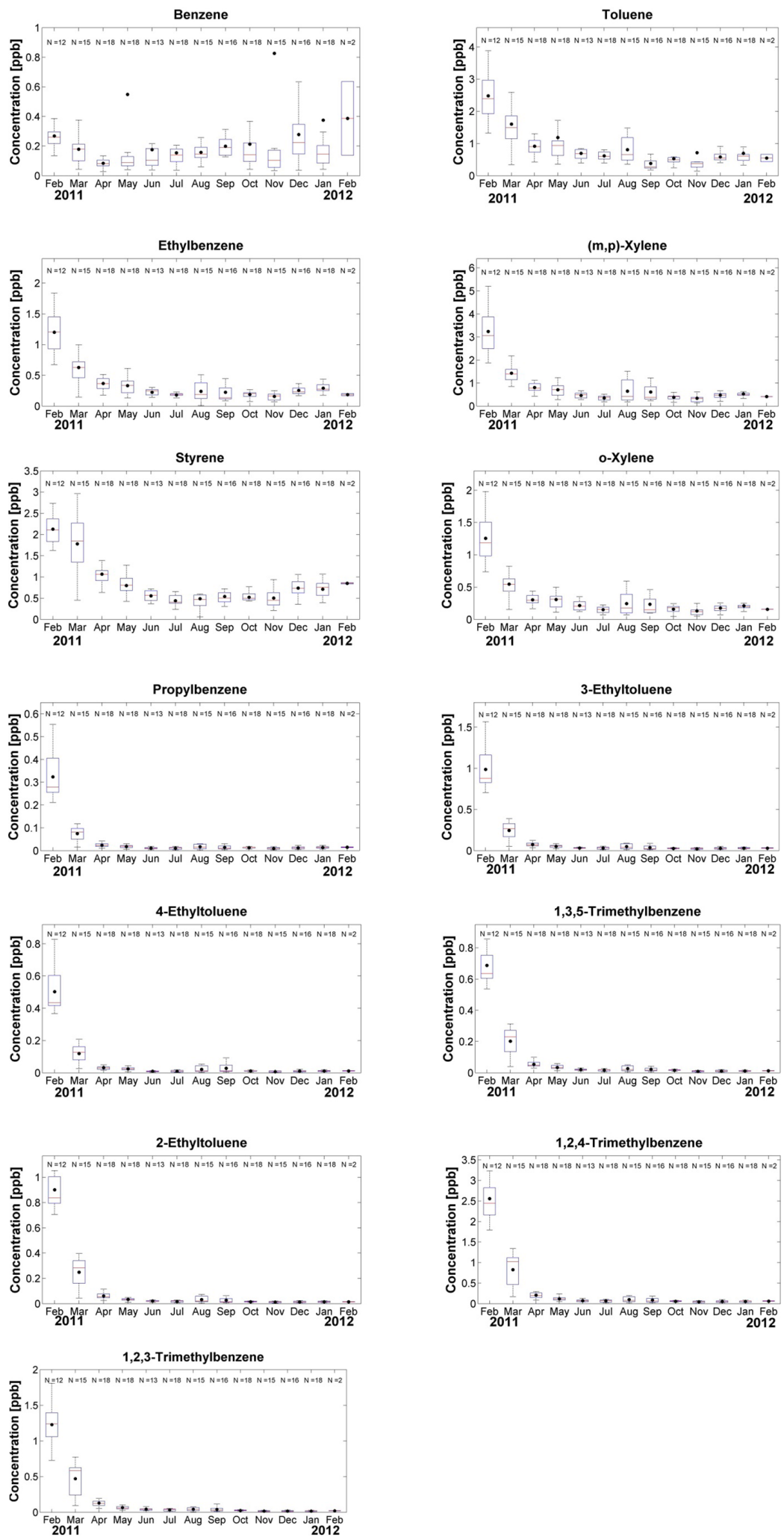

Figure 2. Monthly annual variation in aromatic hydrocarbon concentrations measured during the 1-year sampling period. The red line of each box indicates the median (50th percentile), the black dot the mean, the top and bottom edges of the box the 25th and 75th percentiles, and the whiskers $\pm 2.7 \sigma$ or $99.3 \%$ coverage if the data have a normal distribution (MATLAB, 2010). The values displayed near the top of the graphs indicate the number of samples $(N)$ analysed for each month. 
determined by the emission rate and their atmospheric lifetimes (Parra et al., 2006).

\subsection{Temporal variations}

Although samples were collected during daytime and nighttime in order to identify possible diurnal influences, results indicated no statistically significant differences in the concentrations of aromatic hydrocarbons measured during daytime and night-time. Also, no statistically significant differences were observed between Tuesdays and Saturdays. This indicates that there are no major local sources such as traffic that would result in a distinct diurnal pattern. Therefore, no distinction in the results was made in subsequent sections based on daytime and night-time, or day of the week.

The monthly temporal variations of the measured aromatic hydrocarbons are presented in Fig. 2. These figures indicate the median, mean and 25th and 75th percentiles, as well as \pm 2.7 of the quartiles for each compound (Matlab, 2010). The number of samples collected per month $(\mathrm{N})$ is also provided. In general, no distinct seasonal pattern is observed for any of the compounds measured. The results indicate relatively high values during February 2011 and March 2011 for all the aromatic hydrocarbons, with the exception of benzene. If these higher values coincided with a seasonal cycle, it would have been expected that similar higher values had been observed in the corresponding months in the next year, which was not the case. The reason for these higher levels of aromatic hydrocarbons observed during these 2 months will be explored in Sect. 3.3. No seasonal patterns for BTEX were observed in a previous investigation conducted in the Mpumalanga Highveld and Vaal Triangle (Lourens et al., 2011).

\subsection{Influence of source regions}

Since no distinct seasonal cycles could be identified for the measured aromatic hydrocarbons (Fig. 2), the possible influence of air masses passing over different source regions on the concentration of these compounds was explored. Since VOCs were collected for only four $2 \mathrm{~h}$ sampling periods per week, the allocation of hourly back trajectories to air masses passing over all of the source regions defined by Beukes et al. (2014) was statistically not significant. Therefore, it was decided to group the Johannesburg-Pretoria megacity, the Vaal Triangle and the Mpumalanga Highveld source regions together, since these source regions were identified by Beukes et al. (2014) as the regions with the highest anthropogenic impacts. In this paper, this combined source regions will be referred to as area I. The WBIC, the EBIC and the anticyclonic source regions that lie on the anticyclonic recirculation path of air masses moving towards Welgegund (Beukes et al., 2014) were grouped together and are referred to as area II. Lastly, the "regional background" source region was kept as defined by Beukes et al. (2014). In Fig. 3, the different source regions considered in this study are presented.

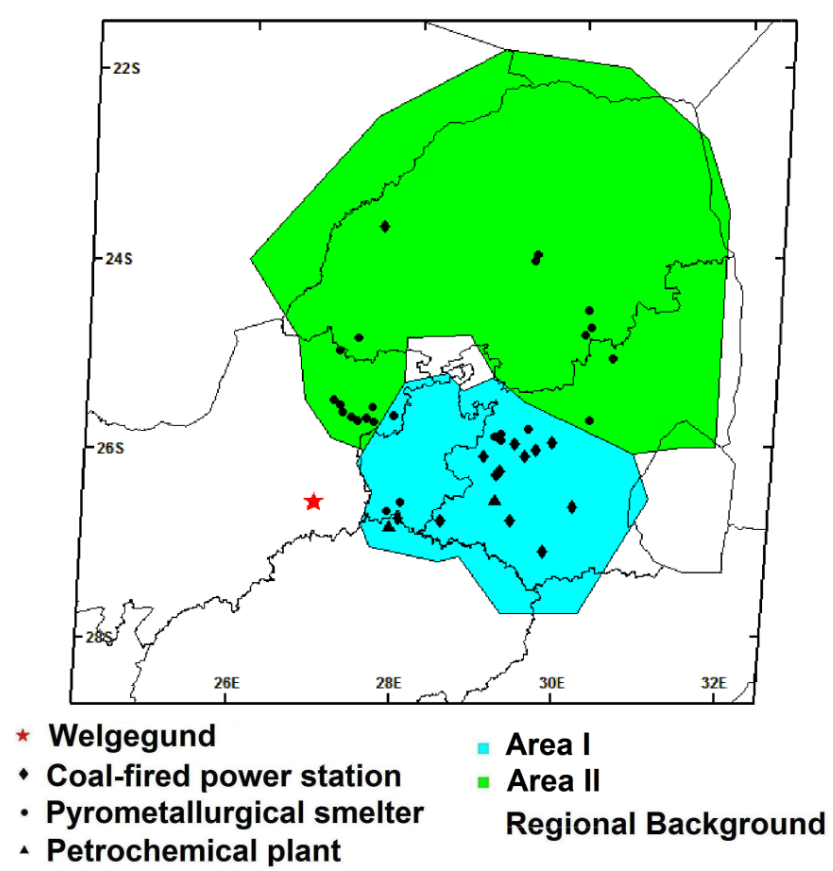

Figure 3. Map of the north-eastern part of South Africa indicating the location of the Welgegund measurement station, large point sources in the industrial hub of South Africa and the source regions defined in this study.

For the entire VOC measurement period, 582 back trajectories were generated. Back trajectory sets, i.e. three trajectories per sampling period, were classified as passing over the different source regions defined in Fig. 3. For the two anthropogenically influenced source regions, i.e. areas I and II, only back trajectory sets that had passed over one of these source regions were considered. Therefore, back trajectory sets that had passed over both these source regions were not considered in further discussions on the influence of source regions. Back trajectory sets were considered as passing over the regional background if such trajectories did not pass over either area I or II, or both area I and II. Taking this into consideration, $86 \%$ of all back trajectory sets could be classified as passing over just one of the three source regions defined.

In Fig. 4, the back trajectories of air masses passing over the different source region are presented. In total, $39 \%$ of the VOC samples were collected during periods when air mass back trajectory sets had passed over area II, while 33 and $14 \%$ of VOC samples were collected when air mass back trajectory sets passed over the regional background and area I, respectively. The reason for the lower percentage of air masses passing over area I can be attributed to the persistence of the anticyclonic circulation pattern over the interior of South Africa, which favours the arrival of air masses at Welgegund from the north to north-eastern sector.

In Fig. 5, the monthly fractional distribution of VOC samples collected during periods when air mass back trajectory 


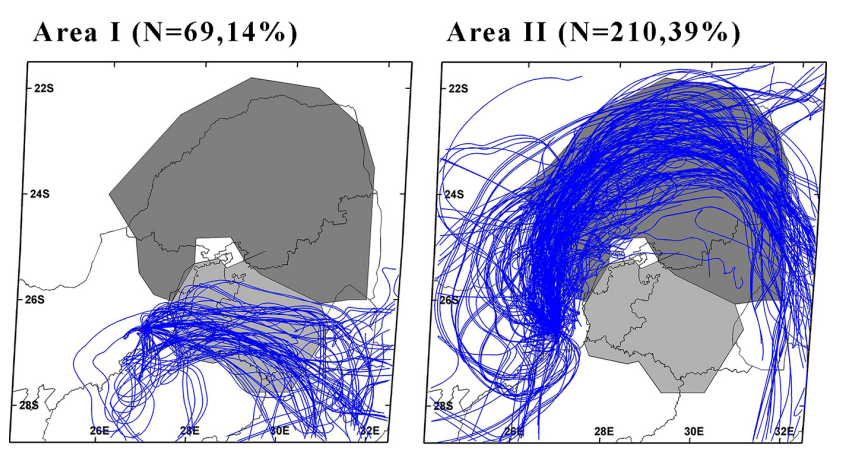

Regional Background $(\mathrm{N}=183,33 \%)$

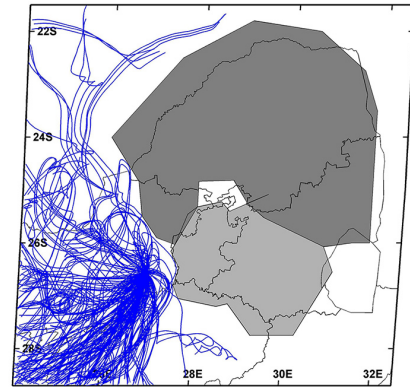

Figure 4. Graphical representations of back trajectories considered as passing over the defined source regions. The percentage of the trajectories considered as passing over a specific source region and the number of trajectories it represents are provided in brackets.

sets had passed over the different source regions is presented. In this figure, air masses that had passed over multiple source regions were defined as mixed. The monthly fractional distribution (Fig. 5) can possibly be used to explain the lack of seasonal pattern observed for the aromatic hydrocarbons (Fig. 2). During February 2011, more than $60 \%$ of the air masses that arrived at Welgegund passed over area I, which consists of the Johannesburg-Pretoria metropolitan conurbation, the Vaal Triangle and the Mpumalanga Highveld. According to Lourens et al. (2012), the Johannesburg-Pretoria megacity is relatively heavily polluted, while both the Vaal Triangle and the Mpumalanga Highveld source regions have been included in areas declared as pollution hotspots (national priority areas) by the South African government (Government Gazette, 2007; Government Gazette, 2005). Considering the high frequency of air masses arriving at Welgegund after passing over area I during the initial period of the study (Fig. 5), the relatively high aromatic hydrocarbon levels measured in February 2011 and March 2011 (Fig. 2) can be related to the relatively polluted air masses arriving during this period. Conversely, during the rest of the study, most of the air masses that arrived at Welgegund passed only over area II and the regional background, which corresponds to lower concentrations measured (Fig. 2). It is therefore postulated that the monthly seasonal cycles presented for the aromatic hydrocarbons (Fig. 2) are not directly related to seasonal pat-

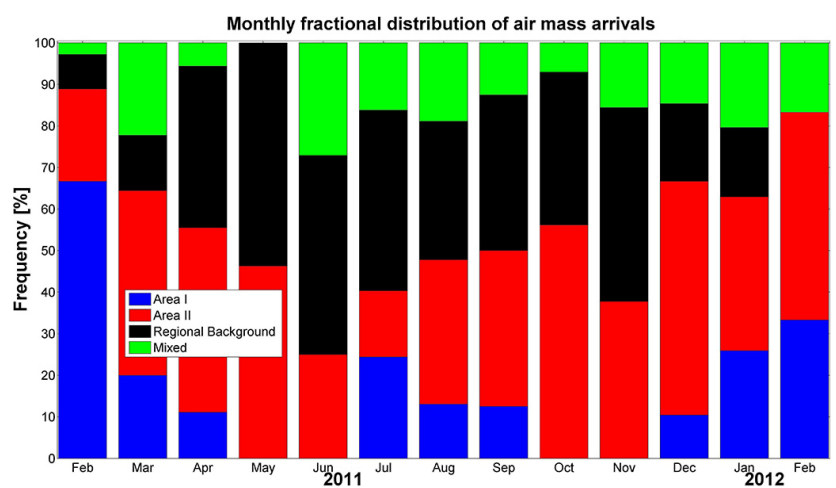

Figure 5. Monthly fractional distribution of VOC samples allocated according to air mass back trajectory sets after passing over the defined source regions.

terns in emissions, but rather depend on the origin of the air masses sampled. Any monthly differences are likely to be a result of month-to-month differences in air mass trajectories. The aforementioned postulation is strengthened by a slight concentration increase in most of the aromatic hydrocarbons observed during August and September 2011 (Fig. 2), which correlated with an increase in frequency of the arrival of air masses that had passed over area I (Fig. 5).

The aromatic hydrocarbon concentrations measured for air masses passing over the three source regions are presented in Fig. 6. As expected, aromatic hydrocarbon concentrations were in general significantly higher for air masses that passed over area I, which are considered to be more polluted. Air masses that passed over area II and the regional background had much lower aromatic hydrocarbon levels and were of the same order. The large point sources in area II are mainly pyrometallurgical smelters (Fig. 2) that produce metals from ores by means of reducing processes (e.g. ferrochromium, as indicated by Beukes et al., 2010, 2012). Aromatic hydrocarbon emissions are not usually associated with these activities and so the relatively low values are expected. In addition, the large point sources in area II are on average further away from Welgegund than the large point sources in area I. This longer travelling time can result in the increased oxidation of the aromatic hydrocarbons. Aromatic hydrocarbons measured in air masses from the regional background can possibly be attributed to smaller cities and agricultural activities in this region, but may also be associated with natural emissions (e.g. Heiden et al., 1999).

\subsection{Inter-compound correlations: an indication of sources}

Several authors (Hoque et al., 2008, and references therein) have performed correlation analyses to determine the possible source(s) for aromatic hydrocarbons. In this section, Pearson's correlation analyses were applied to correlate the concentrations of the different aromatic hydrocarbons 

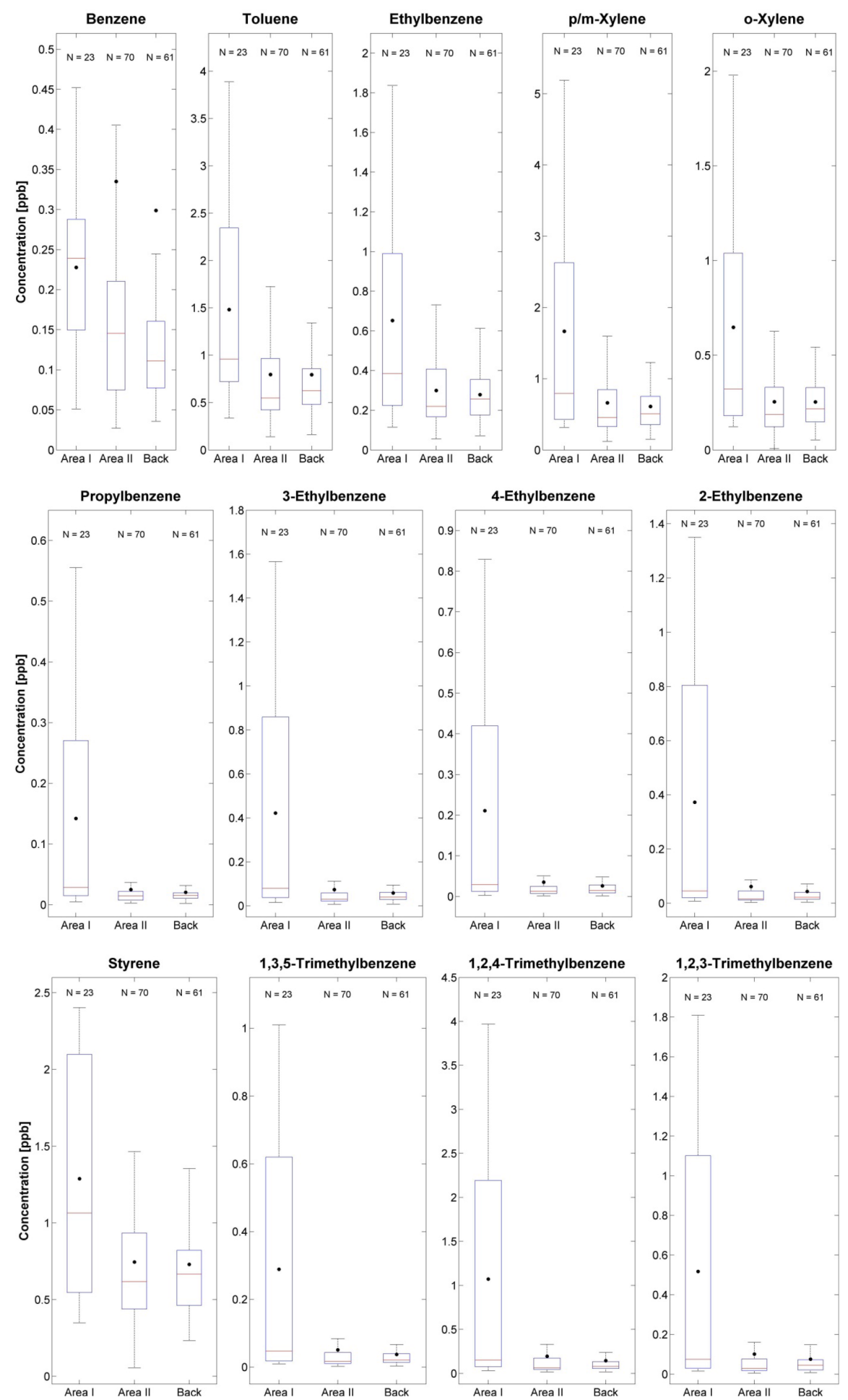

Figure 6. BTEX concentrations measured in air masses arriving at Welgegund, after they had passed over the defined source regions. The red line of each box indicates the median (50th percentile), the black dot the mean, the top and bottom edges of the box the 25th and 75th percentiles, and the whiskers $\pm 2.7 \sigma$ or $99.3 \%$ coverage if the data have a normal distribution (MATLAB, 2010). The values displayed near the top of the graphs indicate the number of samples $(\mathrm{N})$ analysed for each source area. 
measured to one another, as well as to trace gas concentrations for air masses passing over each of the three source regions defined. These correlations are graphically presented in Fig. 7.

For air masses that had passed over area I, relatively good correlations $(r>0.8)$ between the aromatic hydrocarbons were observed, except for benzene. The correlations of benzene with the other aromatic hydrocarbons were less significant, i.e. $r>0.6$. This indicates that all the aromatic hydrocarbons, except possibly benzene, could be from similar sources. Karl et al. (2009) used aircraft flux measurements to show that toluene to benzene ratios can vary greatly $(<$ factor of 3 to $>$ factor of 15) on a spatial scale of tens of kilometres, indicating differences associated with various sources within a region, indicating that a high correlation between benzene and toluene will not always be the case. Large coal-fired power stations and petrochemical operations in source area I, together with vehicle emissions, are expected to be the dominant sources of aromatic hydrocarbons in this source region. Venter et al. (2012) recently indicated that household combustion, which is a very common occurrence in semi- and informal settlements in particular, could also contribute significantly. None of the aromatic hydrocarbons correlated with any of the inorganic gaseous compounds, except benzene, which had a correlation coefficient of 0.612 with CO. Benzene also showed a negative correlation with $\mathrm{O}_{3}$. Both the correlation with $\mathrm{CO}$ and the negative correlation with $\mathrm{O}_{3}$ indicate that benzene was mainly present in fresher plumes arriving at Welgegund. The partial correlation of benzene with $\mathrm{CO}$ indicates that incomplete combustion sources such as vehicle emissions, household combustion and biomass combustion may be the dominant benzene emissions sources in area I.

With the exception of benzene and toluene, the other aromatic hydrocarbons in air masses that had passed over area II correlated relatively well $(r>0.73)$ with one another. Although benzene and toluene did not correlate with the other aromatic hydrocarbons, they correlated relatively well $(r$ $=0.74$ ) with one another. Therefore, it seems that benzene and toluene had a similar source(s), while the other aromatic hydrocarbons had a different source(s). However, neither benzene nor toluene correlated with $\mathrm{CO}$, as was the case for benzene in air masses that had passed over area I. Incomplete combustion sources were therefore unlikely to be the main sources of these two compounds. The nature of large point sources in area II is dramatically different to that of area I. Virtually no large combustion point sources occur in area II, since pyrometallurgical operations mainly focusing on reductive smelting are dominant.

For air masses that had passed over the regional background, benzene correlated well $(r=0.92)$ with toluene. However, in contrast to air masses that had passed over areas I and II, not all of the remaining aromatic hydrocarbons correlated with one another. Only a few significant correlations existed, e.g. ethylbenzene, styrene, $(m, p)$-xylene and

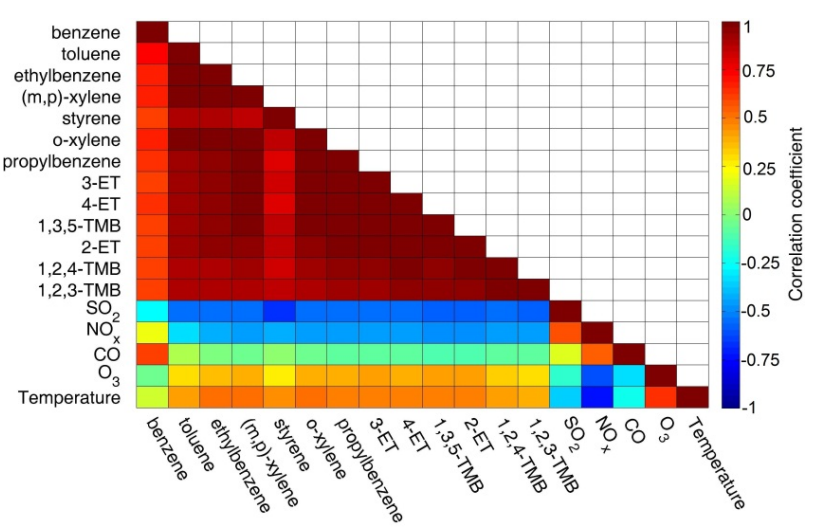

(a)

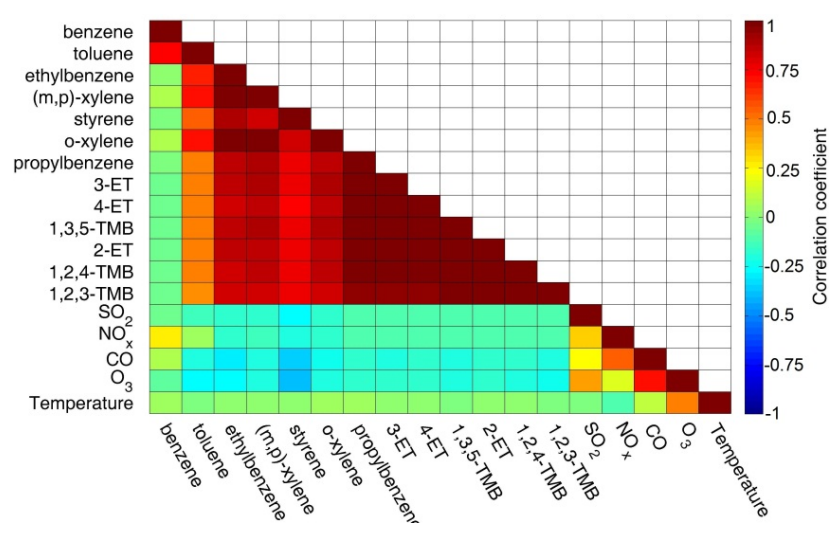

(b)

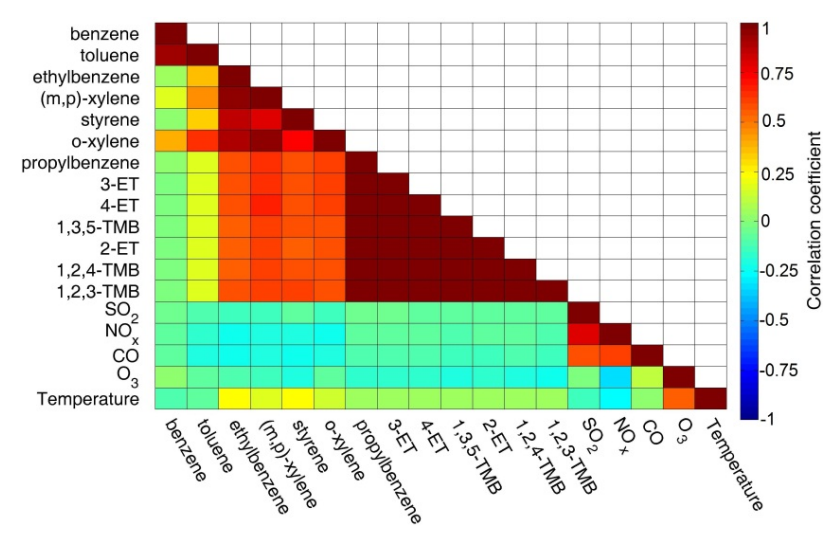

(c)

Figure 7. Correlation analysis for aromatic hydrocarbons with one another and with inorganic trace gases in samples that were collected when back trajectory sets had passed over area I (a), area II (b) and the regional background (c).

$o$-xylene correlated well $(r>0.8)$ with each other. This indicates that the sources of benzene and toluene were again linked but that the sources of the other aromatic hydrocarbons were not necessarily linked. The lower concentrations measured in air masses that had passed over the regional 
Table 1. The aromatic hydrocarbon ratios for the specific source regions.

\begin{tabular}{lcccc}
\hline & Area I & Area II & Regional background & Automotive exhaust \\
\hline toluene/ benzene & 6.51 & 2.38 & 2.66 & $2.7^{\mathrm{a}}$ \\
$(m, p)$-xylene/ benzene & 7.31 & 1.97 & 2.05 & $1.8^{\mathrm{b}}$ \\
$o$-xylene/ benzene & 2.84 & 0.76 & 0.85 & $0.9^{\mathrm{c}}$ \\
ethylbenzene/ benzene & 2.87 & 0.89 & 0.93 & \\
1,3,5-TMB / benzene & 1.27 & 0.15 & 0.13 & \\
styrene/benzene & 5.66 & 2.23 & 2.44 & \\
propylbenzene/benzene & 0.62 & 0.07 & 0.07 & \\
(m,p)-xylene/ ethylbenzene & 2.55 & 2.20 & 2.19 & \\
$o$-xylene/ ethylbenzene & 0.99 & 0.85 & 0.91 & \\
\hline
\end{tabular}

${ }^{\text {a }}$ Brocco et al. (1997), Guicherit (1997), ${ }^{\text {b }}$ Stevenson et al. (1997), ${ }^{\mathrm{c}}$ Guicherit (1997).

background also resulted in more uncertainty, which could lead to lower correlations. Additionally, the natural emissions of aromatic hydrocarbons were also explored. Heiden et al. (1999) proved that some plant species release toluene. Of the species evaluated by Heiden et al. (1999), only sunflower is relevant to the situation at Welgegund - sunflower is the second most common crop species in the area. Heiden et al. (1999) stated that significant diurnal variation in toluene emissions from sunflowers occur, with daytime emissions being a factor of 2 higher than night-time emissions. This was attributed to either differences in photo active radiation (PAR) and/or temperature $(T)$ between daytime and night-time. As is evident from Fig. 7c, toluene did not correlate or anti-correlate with $T$ for the regional background. Therefore, although it is not impossible that vegetation contributes to toluene concentrations measured, it does not seem to be the dominant source.

\subsection{Inter-compound ratios: an indication of sources and aging}

In addition to inter-compound correlations, inter-compound ratios can also be used as an indicative method to determine possible sources for aromatic hydrocarbon and the age of air masses (Hoque et al., 2008, and references therein). The inter-compound ratios of the average atmospheric concentrations of aromatic hydrocarbons with benzene are presented in Table 1. Since most of the aromatic hydrocarbons are more reactive than benzene, the toluene/benzene (T/B), $(m, p)$ xylene / benzene $((m, p)-\mathrm{X} / \mathrm{B}), o$-xylene / benzene $(o-\mathrm{X} / \mathrm{B})$ and $(m, p)$-xylene/ethylbenzene $((m, p)-\mathrm{X} / \mathrm{EB})$ ratios can provide information on the distance from emission sources and the estimated photochemical age of the air mass (Monod et al., 2001; Derwent et al., 2000). The atmospheric T/B ratio, for instance, is usually high close to anthropogenic emissions and will decrease with an increase in distance from the sources (Lee et al., 2002). Globally a T/B ratio below 3 was found to be characteristic of fresh emissions originating from traffic, while a $\mathrm{T} / \mathrm{B}$ ratio $>4.3$ is typical for solvent sources (Lan et al., 2013, and references therein).
As indicated in Table 1, the highest aromatic hydrocarbon ratios were observed for plumes passing over area I, whereas lower ratios were detected in plumes passing over area II and the regional background. The ratios (calculated from the average concentrations) for plumes passing over area I were $6.51,7.31,2.84,2.55$ and 2.87 for $(\mathrm{T} / \mathrm{B}),((m, p)$ $\mathrm{X} / \mathrm{B}),(o-\mathrm{X} / \mathrm{B})((m, p)-\mathrm{X} / \mathrm{EB})$ and $(\mathrm{EB} / \mathrm{B})$, respectively. These ratios indicate the influence of anthropogenic activities in this area, as well as the closer proximity of especially the Johannesburg-Pretoria megacity, which is part of area I, to the Welgegund monitoring station.

The ratios for plumes passing over area II were 2.38, 1.97, 0.76, 2.20 and 0.89 for (T/B), $((m, p)-\mathrm{X} / \mathrm{B}),(o-\mathrm{X} / \mathrm{B})$ $((m, p)-\mathrm{X} / \mathrm{EB})$ and $(\mathrm{EB} / \mathrm{B})$, respectively. As mentioned previously, although anthropogenic activities are also present in this source area, the major industrial activities in this area are not usually associated with high emissions of VOCs. Additionally, sources in area II are also further away from the measurement site compared to sources in area I. The ratios therefore also indicate aged air masses, which might be transported by the dominant anticyclonic circulation pattern of air masses from the industrial hub of South Africa. Therefore, it is likely that most of the aromatic hydrocarbons in air masses that had passed over area II had undergone photochemical degradation.

For air masses passing over the regional background, the aromatic hydrocarbon inter-compound ratios were 2.66 , 2.05, 0.85, 2.19 and 0.93 for (T/B), $((m, p)-\mathrm{X} / \mathrm{B}),(o-\mathrm{X} / \mathrm{B})$ $((m, p)-\mathrm{X} / \mathrm{EB})$ and $(\mathrm{EB} / \mathrm{B})$, respectively. These ratios compared well with the ratios calculated for area II, which also indicate no local sources of atmospheric aromatic hydrocarbons.

According to the literature, the use of solvents (e.g. in paint) is thought to be a major non-traffic source of aromatic hydrocarbons. Brocco et al. (1997) stated that toluene, ethylbenzene and $o, m, p$-xylene (TEX) make up the largest portions of solvents. In Fig. 8, the concentration ratios of TEX/total aromatics for air masses that had passed over the three sources regions are illustrated. The ratios show a 
Table 2. Ozone formation potential of the aromatic hydrocarbon concentrations of air masses passing over the three source regions.

\begin{tabular}{l|ccc|cc|cc}
\hline & \multicolumn{3}{c}{ Area } & \multicolumn{2}{c|}{ Area II } & \multicolumn{2}{c}{ Regional background } \\
\cline { 2 - 7 } & Mean & MIR coefficient & $\mathrm{O}_{3}$ formation potential & Mean & $\mathrm{O}_{3}$ formation potential & Mean & $\mathrm{O}_{3}$ formation potential \\
\hline benzene & 0.228 & 0.42 & 0.096 & 0.335 & 0.141 & 0.299 & 0.125 \\
toluene & 1.482 & 2.70 & 4.001 & 0.796 & 2.148 & 0.796 & 2.148 \\
ethylbenzene & 0.653 & 2.70 & 1.762 & 0.300 & 0.809 & 0.279 & 0.753 \\
$(m, p)$-xylene & 1.665 & 8.20 & 13.653 & 0.661 & 5.418 & 0.612 & 5.014 \\
styrene & 1.288 & 2.20 & 2.834 & 0.746 & 1.641 & 0.730 & 1.607 \\
$o$-xylene & 0.647 & 6.50 & 4.208 & 0.254 & 1.651 & 0.253 & 1.645 \\
propylbenzene & 0.142 & 2.10 & 0.298 & 0.025 & 0.053 & 0.021 & 0.043 \\
$1,3,5-$ TMB & 0.289 & 10.10 & 2.916 & 0.051 & 0.512 & 0.038 & 0.381 \\
$1,2,4-$ TMB & 1.073 & 8.80 & 9.444 & 0.196 & 1.728 & 0.146 & 1.289 \\
$1,2,3$-TMB & 0.518 & 8.90 & 4.608 & 0.101 & 0.900 & 0.076 & 0.674 \\
\hline
\end{tabular}

Note: TMB stands for trimethylbenzene.

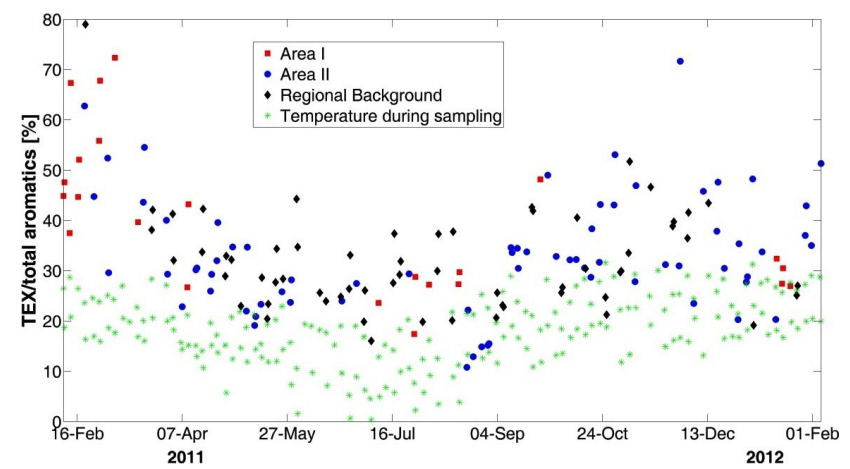

Figure 8. Temporal variation in the concentration ratios of the sum of toluene, ethylbenzene and xylenes (TEX) to total aromatics from air masses arriving at Welgegund after passing over the three source regions.

seasonal pattern with the maximum values in summer and minimum in winter. This is similar to the observation made by Rappenglück and Fabian (1999) who reported that the evaporation of solvents makes a greater contribution to atmospheric VOCs during summer. The average temperatures measured during the sampling periods, as presented in Fig. 8, also indicate a similar pattern than the TEX concentration ratios. This further supports the hypothesis that TEX concentrations are strongly influence by the effect of temperature on evaporation rates. Although not tested in this paper, it is, however, also possible that the differences in aromatic hydrocarbon lifetimes between the different season could result in the aforementioned temporal pattern. It is therefore clear that aromatic hydrocarbons originating from solvents make a contribution to aromatic hydrocarbons in air masses that had passed over all three source regions, including the regional background. However, the magnitude of this contribution was not determined from these data.

\section{6 $\mathrm{O}_{3}$ formation potential of aromatic hydrocarbons}

While the evaluation of aromatic hydrocarbons on a concentration (ppb) basis is of interest in order to assess human exposure to toxic compounds such as benzene, it is also of interest to examine the relative importance of these pollutants pertaining to their role in the production of $\mathrm{O}_{3}$ (Carter, 1994). Beukes et al. (2014), Laakso et al. (2013) and Venter et al. (2012) indicated that $\mathrm{O}_{3}$ is currently the most problematic pollutant in South Africa. Tropospheric $\mathrm{O}_{3}$ impacts air quality, food security (Zunckel et al., 2006) and regional climate change (Fry et al., 2013). Therefore, the relative contributions of aromatic hydrocarbons to photochemical $\mathrm{O}_{3}$ formation in air masses that had passed over the three source regions were examined. Several reactivity scales can be used to estimate $\mathrm{O}_{3}$ formation for specific hydrocarbons. One method that determines the ability of aromatic hydrocarbons to produce $\mathrm{O}_{3}$ entails calculating the product of the average concentration and the maximum incremental reactivity coefficient (MIR) of each compound, i.e. $\mathrm{O}_{3}$ formation potential $=$ VOC $\times$ MIR $($ Carter, 1994). The MIR scale has been used to assess $\mathrm{O}_{3}$ formation potential for aromatic hydrocarbon in numerous previous studies (Hoque et al., 2008; $\mathrm{Na}$ et al., 2005; Grosjean et al., 1998).

The ranking of the aromatic hydrocarbons according to air mass origin for $\mathrm{O}_{3}$ formation potential is provided in Table 2 . As indicated (Table 2), the highest contributions of aromatic hydrocarbon concentrations to $\mathrm{O}_{3}$ formation potential were observed for plumes passing over area $\mathrm{I}$. The $\mathrm{O}_{3}$ formation potential for air masses that had passed over area II and the regional background was of the same order of magnitude. Based on the $\mathrm{O}_{3}$ formation potential values, xylenes $((m, p)$ xylene plus $o$-xylene) are the dominant contributor to $\mathrm{O}_{3}$ formation for air masses that have passed over area I, with 1,2,4trimethylbenzene the second largest contributor. The $\mathrm{O}_{3}$ formation potential of benzene was the lowest, even though it is considered to be the most hazardous compound of the atmospheric aromatic hydrocarbons. As previously stated, the use 
of solvents (e.g. in paint) is thought to be a major non-traffic source of aromatic hydrocarbons, with toluene, ethylbenzene and $o, m, p$-xylene (TEX) making up the largest portion of solvents (Brocco et al., 1997). It was also shown that the ratio of TEX / total aromatic hydrocarbons followed a typical seasonal pattern, demonstrating the contribution from solvents (Fig. 8) in all three source regions. From Table 2 it is evident that TEX contributes significantly to $\mathrm{O}_{3}$ formation relative to the other compounds considered in this paper. The contribution of the evaporation of solvents to $\mathrm{O}_{3}$ formation as a fraction of the overall aromatic hydrocarbons $\mathrm{O}_{3}$ formation potential therefore seems to be significant.

\section{Conclusions}

Benzene is the only VOC listed as a criteria pollutant in the NAAQS, and had an annual average (median) of 0.29 (0.13) ppb, which was well below the South African standard limit of $1.6 \mathrm{ppb}$. Toluene was the most abundant aromatic hydrocarbon, with an annual average (median) concentration of 0.89 (0.63) ppb. Lourens et al. (2011) also previously reported ambient toluene concentrations in the interior of South Africa as being significantly higher than that of benzene. It is therefore recommended that a national air quality threshold for toluene be considered in future. Since the concentrations of ethylbenzene, $(m, p)$-xylene, $o$-xylene and styrene were also of the same order as that of toluene, these compounds could also be considered for inclusion in such legislation.

No statistically significant differences in the concentrations of aromatic hydrocarbons measured during daytime and night-time, or during Tuesdays and Saturdays, were found. This indicates the lack of local sources. However, it should be regarded as an important future perspective to set sampling schedules that would eliminate all possible time-bound biases. This could be achieved with continuous online analysis, which would also enable proper assessment of diurnal cycles and specific case studies. Additionally, no distinct seasonal patterns were observed for any of the compounds measured, which could be attributed to the origin of the air masses sampled. Aromatic hydrocarbon concentrations were in general significantly higher in air masses that had passed over anthropogenically influenced source regions.

Inter-compound correlations indicated that all the aromatic hydrocarbons, except benzene, originated from the same source(s) in area I, where benzene most likely originated from incomplete combustion. For area II and the regional background, benzene and toluene were found to originate from the same source(s), while all the other aromatic hydrocarbons were emitted by a different source(s). Intercompound ratios indicated the influence of anthropogenic activities, especially in area I, and also the closer proximity of the Johannesburg-Pretoria megacity in area I to the Welgegund monitoring station, i.e. less aged plumes. The concentration ratios of TEX/ total aromatics for air masses that had passed over the three sources regions indicated a seasonal dependence, i.e. higher temperatures resulting in higher evaporation rates that contribute to higher ambient concentrations.

The highest contributions of aromatic hydrocarbon concentrations to $\mathrm{O}_{3}$ formation potential were observed for plumes passing over area I. Xylenes $((m, p)$-xylene plus $o$ xylene) were the dominant contributor to $\mathrm{O}_{3}$ formation, with 1,2,4-trimethylbenzene being the second largest contributor. The $\mathrm{O}_{3}$ formation potential of benzene was the lowest.

Acknowledgements. The authors would like to express their appreciation for financial support from the Finnish Academy (project no. 132640), the University of Helsinki, the Finnish Meteorological Institute and the North-West University. The authors also thank Diederik and Jackie Hattingh and their family who are the owners of the commercial farm on which the Welgegund measurement station is situated.

Edited by: J. Rinne

\section{References}

Air Resources Laboratory, 2009. Gridded meteorological data archives, available at: http://www.arl.noaa.gov/archives.php (last access: 12 January 2012).

Arey, J., Obermeyer, G., Aschmann, S. M., Chattopadhyay, S., Cusick, R. D., and Atkinson, R.: Dicarbonyl products of the $\mathrm{OH}$ radical-initiated reaction of a series of aromatics hydrocarbons, Environ. Sci. Technol., 43, 683-689, 2009.

Atkinson, R.: Atmospheric chemistry of VOCs and $\mathrm{NO}_{\mathrm{X}}$, Atmos. Environ., 34, 2063-2101, 2000.

Atkinson, R.: Gas-phase tropospheric chemistry of organic compounds, Journal of Physical and Chemical Reference Data, Monograph, 2, 1-216, 1994.

Bates, M. S., Gonzalez-Flesca N., Sokhi, R. and Cocheo, V.: Atmospheric volatile organic compound monitoring. Ozone induced artefact formation, Environ. Monit. Assess., 65, 89-97, doi:10.1023/A:1006420412523, 2000.

Beukes, J. P., Vakkari, V., van Zyl, P. G., Venter, A. D., Josipovic, M., Jaars, K., Tiitta, P., Laakso, H., Kulmala, M., Worsnop, D., Pienaar, J. J., Järvinen, E., Chellapermal, R., Ignatius, K., Maalick, Z., Cesnulyte, V., Ripamonti, G., Laban, T. L., Skrabalova, L., du Toit, M., Virkkula, A., Siebert S. J., Laakso, L.: Source region plume characterisation of the interior of South Africa, as measured at Welgegund, as measured at Welgegund, in preparation, 2014.

Beukes, J. P., Van Zyl, P. G., and Ras, M.: Treatment of Cr(VI)containing wastes in the South African ferrochrome industry review of currently applied methods, S. African Inst. Min. M., 112, 413-418, 2012.

Beukes, J. P., Dawson, N. F., and Van Zyl, P. G.: Theoretical and practical aspects of $\mathrm{Cr}(\mathrm{VI})$ in the South African ferrochrome industry, S. Afr. Inst. Min. M., 110, 743-750, 2010.

Birdsall, A. W., Andreoni, J. F., and Elrod, M. J.: Investigation of the role of bicyclic peroxy radicals in the oxidation mechanism of toluene, J. Phys. Chem., 114, 10655-10663, 2010. 
Bonn, B., Kulmala, M., Riipinen, I., Sihto, S.-L., and Ruuskanen, T.: How biogenic terpenes govern the correlation between sulphuric acid concentrations and new particle formation, J. Geophys. Res., 113, D12209, doi:10.1029/2007JD009327, 2008.

Brasseur, G, Orlando, J. and Tyndall, G.: Atmospheric chemistry and global change. New York, Oxford University Press, 1007 pp., 1999.

Brocco, D., Fratarcangelli, R., Lepore, L., Petricca, M., and Ventrone, I.: Determination of aromatic hydrocarbons in urban air of Rome, Atmos. Environ., 31, 557-566, 1997.

Burger, J. W.: Identification and comparison of the volatile organic compound concentrations in ambient air in the Cape Town metropolis and the Vaal Triangle, PhD-thesis, North-West University, Potchefstroom, Republic of South Africa, 2006.

Calvert, J. G., Atkinson, R., Becker, K. H., Kamens, R. M., Seinfeld, J. H., Wallington, T. J., and Yarwood, G.: The mechanism of atmospheric oxidation of aromatics hydrocarbons, Oxford University Press, New York, USA, 566 pp., 2002.

Carter, W. P. L.: Development of ozone reactivity scales for volatile organic compounds, J Air Waste Manage, 44, 881-899, 1994

Chiloane, H. J.: Volatile organic compounds (VOCs) analysis from Cape Town haze 11 study, MSc-thesis, University of Witwatersrand, Johannesburg, Republic of South Africa, 80 pp., 2005.

Coeur-Tourneur, C., Henry, F., Janquin, M.-A., and Brutier, L.: Gasphase reaction of hydroxyl radicals with $\mathrm{m}$-, o- and p-cresol, Int. J. Chem. Kin., 38, 553-562, 2006.

Crutzen, P. J. and Andreae, M. O.: Biomass burning in the tropics: Impact on atmospheric chemistry and biogeochemical cycles, Science, 250, 1669-1678, 1990.

Crutzen, P. J., Heidt, L. E., Krasneck, J. P., Pollock, W. H., Seiler,W.: Biomass burning as a source of atmospheric trace gases: $\mathrm{CO}, \mathrm{H}_{2}, \mathrm{~N}_{2} \mathrm{O}, \mathrm{NO}, \mathrm{CH}_{3} \mathrm{Cl}$ and $\mathrm{COS}$, Nature, 282, 253256, 1979.

Derwent, R. G.: Volatile organic compounds in atmosphere, Iss. Environ. Sci. Technol., 4, 1-15, 1995.

Derwent, R. G., Davies, T. J., Delaney, M., Dollard, G. J., Field, R. A., Dumitrean, P., Nason, P. D., Jones, B. M. R., and Pepler, S. A.: Analysis and interpretation of the continuous hourly monitoring data for $26 \mathrm{C}_{2}-\mathrm{C}_{8}$ hydrocarbons at 12 United Kingdom sites during 1996, Atmos. Environ., 34, 297-312, 2000.

Dewulf, J. and Van Langenhove, H.: Analytical techniques for determination of measurement data of 7 chlorinated $\mathrm{C} 1$ and $\mathrm{C} 2$ hydrocarbons and 6 monocyclic aromatic hydrocarbons in remote air masses, Atmos. Environ., 31, 3291-3307, 1997.

Draxler, R. R. and Hess, G. D: Description of the HYSPLIT_4 modeling system. NOAA Tech. Memo. ERL ARL-224, NOAA Air Resources Laboratory, Silver Spring, Marlyland, USA, 24 pp., 1997.

Duce, R. A., Mohnen, V. A., Zimmerman, P. R., Grosjean, D., Cautreels, W. J., Chatfield, R., Jaenicke, R., Ogren, J. A., Pellizzari, E. D., and Wallace, G. T.: Organic material in global troposphere, Rev. Geophys. Space Phys., 21, 921-952, 1983.

Edgerton, S. A., Holdren, M. W., and Smith, D. L.: Inter-urban comparison of ambient volatile organic compound concentrations in US cities, J. Air Poll. Contr. Assoc., 39, 729-732, 1989.

Finlayson-Pitts, B. and Pitts Jr., J. N.: Atmospheric Chemistry: Fundamentals and Experimental Techniques, Wiley, New York, Chichester, Brisbane, 1-1098, 1986.
Fry, M. M., Schwarzkopf, M. D., Adelman, Z., and West, J. J.: Air quality and radiative forcing impacts of anthropogenic volatile organic compound emissions from ten world regions, Atmos. Chem. Phys., 13, 21125-21157, doi:10.5194/acpd-13-211252013, 2013.

Gelencser, A., Siszler, K., Hlavay, J.: Toluene-benzene concentration ratio as a tool for characterizing the distance from vehicular emission sources, Environ. Sci. Technol., 31, 2869-2872, 1997.

Government Gazette Republic of South Africa, 14 October 2005 No. 28132, available at: http://www.info.gov.za/view/ DownloadFileAction?id=73046 (last access: 16 October 13), 2007.

Government Gazette Republic of South Africa, 4 May 2007 No. 29864, available at: http://www.info.gov.za/view/ DownloadFileAction?id=73046 (last access: 16 October 13), 2007.

Government Gazette Republic of South Africa, 2009. 24 December 2009, No. 32816, available at: http://faolex.fao.org/docs/pdf/ saf122986.pdf (last access: 16 October 2013), 2009.

Greenberg, J. P., Guenther, A., Harley, P., Otter, L., Veenendaal, E. M. Hewitt, C. N. James, A. E., and Owen, S. M.: Eddy flux and leaf-level measurements of biogenic VOC emissions from mopane woodland of Botswana, J. Geophys. Res., 108, 8466, doi:10.1029/2002JD002317, 2003.

Grosjean, E., Rasmussen, R. A., and Grosjean, D.: Ambient levels of gas phase pollution in Porto Alegre, Brazil. Atmos. Environ., 32, 3371-3379, 1998.

Guenther, A., Otter, L. B., Zimmerman, P., Greenberg, J., Scholes, R., Scholes, M. C.: Biogenic hydrocarbon emissions from southern Africa savannas, J. Geophys. Res., 101, 25859-25865, 1996.

Guicherit, R.: Traffic as a source of volatile hydrocarbons in ambient air, Science Total Environment, 205, 201-213, 1997.

Harley, P., Otter, L. B., Guenther, A., Greenberg, J.: Micrometeorological and leaf-level measurements of isoprene emissions from a southern African savanna, J. Geophys. Res., 108, 8468, doi:10.1029/2002JD002592, 2003.

Heiden, A. C., Kobel, K., Komenda, M., Koppmann, R., Shao, M., and Wildt, J.: Toluene emissions from plants, Geophys. Res. Lett., 26, 1283-1286, 1999.

Hellén, H., Kuronen, P., and Hakola, H.: Heated stainless steel tube for ozone removal in the ambient air measurements of mono- and sesquiterpenes, Atmos. Environ., 57, 35-40, 2012.

Hellén, H., Hakola, H., Laurila, T., Hiltunen, V., and Koskentalo, T.: Aromatic hydrocarbon and methyl tert-butyl ether measurements in ambient air of Helsinki (Finland) using diffusive samplers, Sci. Total Environ., 298, 55-64, 2002.

Hewitt, C. N.: Reactive hydrocarbons in the atmosphere, San Diego, CA, Academic Press, 322 pp., 1999.

Hirsikko, A., Vakkari, V., Tiitta, P. Manninen, H. E., Gagné, S., Laakso, H., Kulmala, M., Mirme, A., Mirme, S., Mabaso, D., Beukes, J. P., and Laakso, L..: Characterisation of sub-micron particle number concentrations and formation events in the western Bushveld Igeneous Complex, South Africa, Atmos. Chem. Phys., 12, 3951-3967, doi:10.5194/acp-12-3951-2012, 2012.

Hoque, R. R., Khillare, P. S., Agarwal, T., Shridhar, V., and Balachandran, S.: Spatial and temporal variation of BTEX in the urban atmosphere of Delhi, India, Sci. Total Environ., 392, 30-40, 2008. 
Johnson, D., Jenkin, M., Wirtz, K., and Martin-Reviejo, M.: Simulating the formation of secondary organic aerosol from the photooxidation of toluene, Environ. Chem., 1, 150-165, 2004.

Johnson, D., Jenkin, M. E., Wirtz, K., and Martin-Reviejo, M.: Simulating the formation of secondary organic aerosol from the photooxidation of aromatics hydrocarbons, Environ. Chem., 2, 3548, 2005.

Jose, M. B., Rose, D., and Josep, C.: Applying receptor models to analyze urban/suburban VOCs air quality in Martorell (Spain), Environ. Sci. Technol., 32, 405-412, 1998.

Karl, T., Apel, E., Hodzic, A., Riemer, D. D., Blake, D. R., Wiedinmyer, C.: Emissions of volatile organic compounds inferred from airborne flux measurements over a megacity, Atmos. Chem. Phys., 9, 271-285, doi:10.5194/acp-9-271-2009, 2009.

Kostiainen, R.: Volatile organic compounds in the indoor air of normal and sick houses, Atmos. Environ., 29, 693-702, 1995.

Kourtidis, K. A., Ziomas, I. C., Rappenglueck, B., Proyou, A., and Balis, D.: Evaporative traffic hydrocarbon emissions, traffic CO and speciated HC traffic emissions from the city of Athens, Atmos. Environ., 33, 3831-3842, 1999.

Kuran, P. and Sojak, L.: Environmental analysis of volatile organic compounds in water and sediment by gas chromatography, J. Chrom. A, 733, 119-141, 1996.

Laakso, L., Koponen, I. K., Mönkkönen, P., Kulmala, M., Kerminen, V.-M., Wehner, B., Wiedensohler, A., Wu, Z., Hu, M.: Aerosol particles in the developing world; a comparison between New Delhi in India and Beijing in China,Water Air Soil Poll., 1-16, 5-20, doi:10.1007/s11270-005-9018-5, 2006.

Laakso, L., Laakso, H., Aalto, P. P., Keronen, P., Petäjä, T., Nieminen, T., Pohja, T., Siivola, E., Kulmala, M., Kgabi, N., Phalatse, D., Molefe, M., Mabaso, D., Pienaar, and J. J., and Kerminen, V.-M.: Basic characteristics of atmospheric particles, trace gases and meteorology in a relatively clean Southern African Savannah environment, Atmos. Chem. Phys., 8, 4823-4839, doi:10.5194/acp-8-4823-2008, 2008.

Laakso, L., Merikanto, J., Vakkari, V., Laakso, H., Kulmala, M., Molefe, M., Kgabi, N., Mabaso, D., Carslaw, K. S., Spracklen, D. V., Lee, L. A., Reddington, C. L., and Kerminen, V.-M.: Boundary layer nucleation as a source of new $\mathrm{CCN}$ in savannah environment, Atmos.Chem. Phys., 13, 1957-1972, doi:10.5194/acp13-1957-2013, 2013.

Lan, T. T. N. and Minh, P. A.: BTEX pollution caused by motorcycles in the megacity of HoChiMinh, J. Environ, Sci., 25(2), 348-356, 2013.

Lee, S. C., Chiu, M. Y, Ho, K. F., Zou, S. C., and Wang, X.: Volatile organic compounds (VOCs) in urban atmosphere of Hong Kong, Chemosphere, 48, 375-382, 2002.

Liu, C., Xu, Z., Du, Y., and Guo, H.: Analyses of volatile organic compounds concentrations and variation trends in the air of Changchun, the northeast of China, Atmos. Environ., 34, 44594466, 2000.

Liu, J., Mu, Y., Zhang, Y., Zhang, Z., Wang, X., and Liu, Y. : Atmospheric levels of BTEX compounds during the 2008 Olympic Games in the urban area of Beijing, Sci. Tot. Environ., 408, 109116, 2009.

Lobert, J. M., Scharffe, D. H., Hao, W. M., and Crutzen, P. J.: Importance of biomass burning in the atmospheric budgets of nitrogencontaining gases, Nature, 346, 552-554, 1990.
Lourens, A. S, Beukes, J. P, Van Zyl, P. G., Fourie, G. D., Burger, J. W, Pienaar, J. J., Read, C. E., and Jordaan, J. H.: Spatial and temporal assessment of gaseous pollutants in the Highveld of South Africa, S. Afr. J. Sci., 107, 8 pp., doi:10.4102/sajs.v107i1/2.269, 2011.

Lourens, A. S. M., Butler, T. M., Beukes, J. P., Van Zyl, P. G., Beirle, S., Wagner, T., Heue, K-P., Pienaar, J. J., Fourie, G. D., and Lawrence, M. G.: Re-evaluating the $\mathrm{NO}_{2}$ hotspot over the South African Highveld, S. Afr. J. Sci., 108, 6 pp., doi:10.4102/sajs.v108i11/12.1146.1146, 2012.

MATLAB. Version 7.10.0 (R2010a). 24 Prime Park Way, Natick, MA, 01760-1500, USA, The MathWorks Inc., 2010.

Monod, A., Sive, B. C., Avino, P., Chen, T., Blake, D. R., Rowland, F. S.: Monoaromatic compounds in ambient air of various cities: a focus on correlations between the xylenes and ethylbenzene, Atmos. Environ., 35, 135-149, 2001.

Mukund, R., Kelly, T. J., and Spicer, C. W.: Source attribution of ambient air toxics and other VOCs in Colombus Ohio, Atmos. Environ., 30, 3457-3470, 1996.

Na, K., Moon, K.-C., and Kim, Y. P.: Source contribution to aromatic VOC concentration and ozone formation potential in the atmosphere of Seoul, Atmos. Environ., 39, 5517-5524, 2005.

Olariu, R. I., Klotz, B., Barnes, I., Becker, K. H., and Mocanu, R.: FT-IR study of the ring-retaining products from the reaction of $\mathrm{OH}$ radicals with phenol, o-, m-, and p-cresol, Atmos. Environ., 36, 3685-3697, 2002.

Otter, L. B., Guenther, A., and Greenberg, J.: Seasonal and spatial variations in biogenic hydrocarbon emissions from southern African savannas and woodlands, Atmos. Environ., 36, 42654275, 2002a.

Otter, L. B., Scholes, R. J., Dowty, P., Privette, J., Caylor, K., Ringrose, S., Mukelabai, M., Frost, P., Hanan, N., Totolo, O., and Veenendaal, E. M.: The Southern African Regional Science Initiative (SAFARI 2000): Wet season campaigns, S. Afr. J. Sci., 98, 131-137, 2002b.

Parra, M. A., Elustondo, D., and Garrigo, J.: Spatial and temporal trends of volatile organic compounds (VOC) in a rural area of northern Spain, Sci. Total Environ., 370, 157-167, 2006.

Penkett, S. A., Blake, N. J., Lightman, P., Marsh, A. R. W., and Anzwyl, P.: The seasonal variation of nonmethane hydrocarbons in the free troposphere over the North Atlantic Ocean: possible evidence for extensive reaction of hydrocarbons with the nitrate radical, J. Geophys. Res., 98, 2865-2885, 1993.

Petäjä, T., Vakkari, V., Pohja, T., Nieminen, T., Laakso, H., Aalto, P. P., Keronen, P., Siivola, E., Kerminen, V.-M., Kulmala, M., and Laakso, L.: Transportable aerosol characterization trailer with trace gas chemistry: design, instruments and verification, Aerosol Air Qual. Res., 13, 421-435, 2013.

Simon, V., Baer, M., Torres, L., Olivier, S., Meybeck, M., and Della Massa, J. P.: The impact of reduction in the benzene limit value in gasoline on airborne benzene, toluene and xylenes levels, Sci. Total Environ., 334-335, 177-183, 2004.

Stevenson, K. J., Stacey, B., and Willis, P. G.: Air Quality at Heathrow Airport, Annual Report for 1996, AEA Technology, London, UK, 1997.

Rappenglück, B. and Fabian, P.: Non-methane hydrocarbons (NMHC) in the Greater Munich Area/Germany, Atmos. Environ., 33, 3843-3857, 1999. 
Srivastava, A., Sengupta, B., and Dutta, S. A.: Source apportionment of ambient VOCs in Delhi city, Sci. Total Environ., 343, 207-220, 2005.

Swap, R. J., Annegarn, H. J., and Otter, L. B.: Southern African Regional Science Initiative (SAFARI 2000): Summary of science plan, S. Afr. J. Sci., 98, 119-124, 2002a.

Swap, R. J., Annegarn, H.J., Suttles, J. T., Haywood, J., Helmlinger, M. C., Hely, C., Hobbs, P. V., Holben, B. N., Ji, J., King, M. D., Landmann, T., Maenhaut, W., Otter, L., Pak, B., Piketh, S. J., Platnick, S., Privette, J., Roy, D., Thompson, A. M., Ward, D., Yokelson, R.: The Southern African Regional Science Initiative (SAFARI 2000): Overview of the dry season field campaign, S. Afr. J. Sci., 98, 125-130, 2002b.

Sweet, C.W. and Vermette, S. J.: Toxic volatile organic compounds in urban air in Illinois, Environ. Sci. Technol., 26, 165-173, doi:10.1021/es00025a020, 1992.

Takekawa, H., Minoura, H., and Yamazaki, S.: Temperature dependence of secondary organic aerosol formation by photo-oxidation of hydrocarbons, Atmos. Environ., 37, 3413-3424, 2003.

Tiitta, P., Vakkari, V., Josipovic, M., Croteau, P., Beukes, J. P., van Zyl, P. G., Venter, A. D., Jaars, K., Pienaar, J. J., Ng, N. L., Canagaratna, M. R., Jayne, J. T., Kerminen, V.-M., Kulmala, M., Laaksonen, A., Worsnop, D. R., and Laakso, L.: Chemical composition, main sources and temporal variability of PM1 aerosols in southern African grassland, Atmos. Chem. Phys., 14, 19091927, doi:10.5194/acp-14-1909-2014, 2014.

Tunved, P., Hansson, H.-C., Kerminen, V.-M., Ström, J., Dal Maso, M., Lihavainen, H., Viisanen, Y., Aalto, P. P., Komppula, M., and Kulmala, M.: High natural aerosol loading over Boreal forests, Science, 312, 261-263, 2006.
Tyson, P. D., Garstang, M., and Swap, R.: Large-scale recirculation of Air over Southern Africa, J. Appl. Meteorol., 35, 2218-2236, 1996.

Vakkari, V., Laakso, H., Kulmala, M., Laaksonen, A., Mabaso, D., Molefe, M., Kgabi, N., and Laakso, L.: New particle formation events in semi-clean South African savannah, Atmos. Chem. Phys., 11, 3333-3346, doi:10.5194/acp-11-3333-2011, 2011.

van der Walt, H.J.: The impact of hydrocarbons emissions on regional air quality in a South African metropolitan area, $\mathrm{PhD}$ thesis, North-West University, Potchefstroom, Republic of South Africa, 2008.

Venter, A. D., Vakkari, V., Beukes, J. P., Van Zyl, P. G., Laakso, H., Mabaso, D., Tiitta, P., Josipovic, M., Kulmala, M., Pienaar, J. J., and Laakso, L.: An air quality assessment in the industrialised western Bushveld Igneous Complex, South Africa, S. Afr. J. Sci., 108, 1059, doi:10.4102/sajs.v108i9/10.1059, 2012.

Volkamer, R., Klotz, B., Barnes, I., Imamura, T., and Washida, N.: $\mathrm{OH}$-initiated oxidation of benzene Part 1. Phenol formation under atmospheric conditions, Phys. Chem. Chem. Phys., 4, 15981610, 2002.

Welgegund, available at: http://www.welgegund.org/ (last access: 3 January 2012), 2012.

WHO: Air quality guidelines for Europe, 2nd edition. Copenhagen: WHO Regional Publications; European Series, No. 91, 2000.

Zunckel, M., Koosailee, A., Yarwood, G., Maure, G., Venjonoka, K., Van Tienhoven, A. M. and Otter, L.: Modelled surface ozone over southern Africa during the cross border air pollution impact assessment project, Environ. Modell. Softw., 21, 911-924, 2006. 